\title{
IMPLEMENTASI PERLINDUNGAN KONSUMEN DALAM TRANSAKSI PERBANKAN MENURUT KAJIAN UU NO. 21 TAHUN 2008 TENTANG PERBANKAN SYARIAH
}

\author{
Febriani Nur Fadilla \\ Magister Hukum Universitas Semarang, Semarang
}

\begin{abstract}
ABSTRAK
Tujuan Penelitian ini adalah untuk menganalisa implementasi perlindungan konsumen dalam transaksi perbankan. Undang - Undang No. 10 Tahun 1998 tentang Perbankan pada Pasal 1 ayat (14) menyebutkan bahwa prinsip Bank Syariah antara lain prinsip bagi hasil (mudharabah), pembiayaan berdasarkan prinsip penyertaan modal (musharakahl), prinsip jual beli barang dengan memperoleh keuntungan (murabahah), atau pembiayaan barang modal berdasarkan prinsip sewa murni tanpa pilihan (ijarah), atau dengan adanya pilihan pemindahan kepemilikan atas barang yang disewa dari pihak bank oleh pihak lain (ijarah wa iqtina). Kegiatan perbankan nasabah menjadi prioritas, dilihat dari perspektifnya banyak hal yang mempengaruhi kepuasan nasabah (konsumen). Maka dapat dipahami bahwa Bank Syariah selain meningkatkan mutu kualitas juga memperhatikan perlindungan resiko terhadap nasabah. Namun dalam praktiknya belum terdapat pengaturan tertulis yang terdapat dalam UU No. 21 Tahun 2008 yang berkaitan dengan sistem perlindungan konsumen. Metode pengumpulan data dalam penelitian ini adalah menggunakan metode studi pustaka dan studi dokumenter. Hasil penelitian adalah mengenai pelaksanaan perlindungan konsumen di dunia perbankan. Melalui peraturan yang jelas mengenai perlindungan konsumen, diharapkan dapat terciptanya kegiatan perbankan yang saling menguntungkan antara beberapa pihak tanpa menimbulkan kerugian pada salah satu pihak. Disisi lain dengan adanya peraturan yang jelas, maka muncul kepastian hukum yang dapat dipatuhi oleh pihak yang berkepentingan
\end{abstract}

Kata Kunci : Bank Syariah; undang-undang; perlindungan konsumen 


\title{
IMPLEMENTATION OF CONSUMER PROTECTION IN BANKING TRANSACTIONS ACCORDING TO STUDY NO. 21 OF 2008 CONCERNING SHARIA BANKING
}

\author{
Febriani Nur Fadilla \\ Master of Law, University of Semarang, Semarang
}

\begin{abstract}
The purpose of this study is to analyze the implementation of consumer protection in banking transactions. Law No. 10 of 1998 concerning Banking in Article 1 paragraph (14) states that the principles of Islamic Banks include profit sharing principles (mudharabah), financing based on the principle of equity participation (musharakahl), the principle of buying and selling goods by obtaining profits (murabahah), or financing of capital goods based on the principle of pure lease without choice (ijarah), or with the choice of transfer of ownership of goods leased from the bank by another party (ijarah wa iqtina). Customer banking activities become a priority, seen from his perspective many things affect customer satisfaction (consumers). Then it can be understood that in addition to improving the quality of Islamic Bank quality also pay attention to risk protection for customers. But in practice there is no written regulation contained in Law No. 21 of 2008 relating to consumer protection systems. The data collection method in this research is to use the literature study and documentary study methods. The results of the study are concerning the implementation of consumer protection in the banking world. With the existence of clear regulations concerning consumer protection, it is hoped that banking activities can be mutually beneficial between several parties without causing harm to either party. On the other hand, with clear regulations, legal certainty emerges which can be followed by interested parties
\end{abstract}

Keywords: Sharia Bank; law; consumer protection 


\section{A. PENDAHULUAN}

Menurut Undang-Undang RI No. 10 Tahun 1998 tanggal 10 November 1998 tentang Perbankan, perbankan adalah badan usaha yang menghimpun dana dari masyarakat dalam bentuk simpanan dan menyalurkannya kepada masyarakat dalam bentuk kredit ( pembiayaan ) dan bentuk-bentuk lainnya dalam rangka meningkatkan taraf hidup masyarakat banyak ${ }^{1}$. Perkembangan ekonomi nasional maupun internasional yang selalu mengalami peningkatan turut menjadi alasan muncul berbagai macam bank di Indonesia.

Bank merupakan pemasok dari sebagian besar uang yang beredar, digunakan sebagai alat tukar atau alat pembayaran sehingga mekanisme kebijaksaaan moneter dapat berjalan. Hal tersebut dapat dimaknai bahwa, baik Bank Sentral atau Bank Syariah merupakan suatu lembaga keuangan yang memegang peran penting terhadap perekonomian masyarakat. Bank umum atau bank komersial dalam kegiatannya dibina dan diawasi oleh bank sentral, sedangkan bank sentral dalam menjalankan tugas pokoknya berdasarkan kebijaksanaan dari Pemerintah.

Bank dengan fungsinya sebagai pihak - pihak yang menyimpan dan menyalurkan dana, bank juga melayani kebutuhan pembiayaan serta melancarkan mekanisme perekenomian masyarakat. Demi tetap menjadi lembaga kepercayaan masyarakat, pemerintah harus melindungi masyarakat dari tindakan lembaga atau oknum pegawai bank yang tidak bertanggung jawab dan merusak citra serta kepercayaan masyarakat. Fungsi bank terlebih lanjut adalah sebagai financial

\section{hlm. 25}

\footnotetext{
${ }^{1}$ Kasmir, Bank dan Lembaga Keuangan Lainnya ( Jakarta: PT. Grafindo Persada, 2011) cet-7
} 
intermedidiary yang berarti sebagai lembaga pembayaran. Perbankan nasional berfungsi sebagai sarana pemberdayaan masyarakat dan seluruh kekuatan ekonomi nasional.

Bank merupakan lembaga keuangan yang mempunyai peranan yang sangat strategis dalam menyelesaikan dan mengembangkan unsur-unsur trilogy pembangunan nasional. Kegiatan utama dari perbankan adalah menyerap dana dari masyarakat. Hal ini terutama karena fungsi bank sebagai perantara (intermediary) pihak-pihak kelebihan dana (surplus of funds) dan pihak yang memerlukan dana (luck of funds). Sebagai agent of development, bank merupakan alat pemerintah dalam membangun perekonomian bangsa melalui pembiayaan semua jenis usaha pembangunan, yaitu sebagai financial intermediary (perantara keuangan) yang memberikan kontibusi terhadap pendapatan Negara. ${ }^{2}$

Perkembangan Bank Syariah di Indonesia mengalami perkembangan yang sangat pesat, dibuktikan dengan munculnya berbagai macam bank syariah dengan penawaran- penawaran yang menguntungkan konsumen. Sebagai lembaga perantara financial yang melakukan mekanisme pengumpulan dan penyaluran dana secara seimbang, sesuai ketentuan yang berlaku³ ${ }^{3}$ Di Indonesia bank dibedakan menjadi dua, yakni bank konvensional ( bank umum ) dan bank syariah. Berbeda dari bank konvensional yang mengenal bunga dalam transaksinya, bank syariah yang menganut ajaran Islam menggunakan sistem bagi hasil sesuai syariat Islam.

Menurut ajaran islam lembaga pebankan adalah suatu institusi perekonomian yang merupakan wujud muamalah. Perbankan sebagai salah satu institusi ekonomi dalam sistem ekonomi islam. Sistem ekonomi islam memiliki

${ }^{2}$ Abdullah Kelib, Sodkul Amin, Analisis Terhadap Pelaksanaan Aqad Pembiayaan Dengan Prinsip Mudharabah Pada Bank Syariah Dalam Kajian UU No. 21 Tahun 2008 Tentang Perbankan Syariah, Jurnal Ius Constituendum Vol 2 No 1, Magister Hukum Universita Semarang, 2017 Semarang, hlm 41.

${ }^{3}$ Dewi Nurul Musjtari, Penyelesaian Sengketa dalam Praktik Perbankan Syariah, (Yogyakarta: Nuha Medika, 2012), hlm 2. 
pengertian adalah sistem ekonomi yang kebijakan - kebijakan atau keputusan keputusan yang diambil dalam melaksanakan kebijakan ekonomi dipengaruhi/ dilandasi oleh syariah islam ${ }^{4}$. Setelah dikaji lebih dalam Bank Syariah transaksinya berprinsip pada tiga hal yaitu, efisiensi, keadilan dan kebersamaan. Efisiensi mengacu pada prinsip saling membantu secara sinergis untuk memperoleh keuntungan/ margin sebesar mungkin.

Keadilan mengacu pada hubungan yang tidak dicurangi, ikhlas dengan persetujuan yang matang atau proporsi masukan dan pengeluaran sama. Kebersamaan mengacu pada prinsip saling menawarkan bantuan dan nasihat untuk saling meningkatkan produktivitas ${ }^{5}$. Perekonomian islam berpedoman pada prinsip - prinsip ekonomi islam antara lain : manusia adalah makhluk Allah untuk memakmurkan kehidupan di bumi, diberi kedudukan sebagai khalifah (wakil Nya) yang wajib melaksanakan petunjuk - Nya; Kerja adalah sesungguhnya menghasilkan (produktif); Islam menentukan berbagai macam bentuk kerja yang halal dan yang haram, kerja yang halal saja yang dipandang sah; Hak milik manusia dibebani kewajiban - kewajiban yang diperuntukkan bagi kepentingan masyarakat ${ }^{6}$.

Melalui hal tersebut diatas dapat diperhatikan jika prinsip - prinsip syariah dalam ekonomi Bank Syariah dijalankan dengan tidak mendasarkan kepada prinsip bunga karena dianggap riba dan dilarang. Secara garis umumbank syariah merupakan lembaga keuangan yang operasionalnya dan produk-produknya berlandaskan Al-Quran dan Hadist.Bank syariah muncul sebagai solusi ditengah persoalan yang mempertentangkan bunda/ riba',Imam Syafi'i menjelaskan bahwa

\footnotetext{
${ }^{4}$ Amin Aziz, Tantangan, Prospek dan Strategi Sistem Perekonomian syariah di Indonesia dilihat dari pengalaman pengembangan BMTJakarta, PINBUK, 1996,) hlm. 2.

${ }^{5}$ Edy Wibowo, Mengapa Memilih Bank Syariah? (Bogor, Ghalia Indonesia, 2015) hlm 33

${ }^{6}$ Ahmad Ashar Basyir, artikel pada Berbagai Aspek Ekonomi Islam (editor M. Rusli Karim), (Yogyakarta, P3EI - FE UII bekerjasama dengan Penerbit Tiara Wacana, 1992), hlm. 13-14.
} 
hukum bertransaksi jual beli adalah mubah (diperbolehkan) sedangkan riba atau bunga termasuk yang diharamkan ${ }^{7}$.

Dalam bank syariah, untuk menarik minat customer( nasabah ) pihak bank akan menawarkan bagi hasil atau bagi hadiah. Keuntungan dari kegiatan perbankan ini adalah dengan cara bagi hasil. Akadnya biasanya ditetapkan di awal perjanjian dengan persetujuan kedua belah pihak beserta penjelasan untung ruginya.Sistem bagi hasil pada bank syariah ditentutkan dari besarnya rasio atau nisbah yang tentunya turut dibuat akadnya saat awal perjanjian. Sisi lainnya, jumlah pembagian bagi hasil akan meningkat sesuai dengan peningkatan jumlah konvensional ${ }^{8}$. Dari survey yang pernah dilakukan, kebanyakan bank syariah masih mengedepankan akad jual-belinya. Diantaranya adalah Murabahah dan AlBa'i Bitsaman Ajil'.

Disamping keuntungan-keuntungan yang didapat nasabah dari lembaga bank, muncul pula resiko-resiko yang dapat merugikan. Konsekuensi yang timbul dari aktifitas perbankan yang kemungkinan timbul turut menjadi perhatian pemerintah untuk melindungi masyarakat dari resiko-resiko yang mungkin muncul dari aktifitas perbankan.

\section{B. PERUMUSAN MASALAH}

Berdasarkan latar belakang masalah, maka perumusan masalah yang dapat penulis uraikan sebagai berikut :

1. Bagaimana Implementasi perlindungan konsumen dalam transaksi Perbankan Syariah ?

2. Bagaimana kendala dan solusi terhadap perlindungan konsumen dalam transaksi Perbankan Syariah menurut kajian UU No. 21 tahun 2008?

${ }^{7}$ Ahmad Nahrawi, Ensiklopedia Imam Syafi'I terj. Usman Sya'roni ( Jakarta, PT. Mizan Publika, 2008) hlm. 258

${ }^{8}$ Muhammad Syafi'i. Antonio, Bank Syariah Dari Teori ke Praktik, ( Jakarta: Gemma Insani Perss, 2001 ) hlm. 61

${ }^{9}$ Muhammad, Tehnik Perhitungan Bagi Hasil dan Profit Margin Pada Bank Syariah ( Yogyakarta: UII Press, 2001 ) hlm. 39 


\section{TINJAUAN PUSTAKA}

\section{Pengertian Bank Syariah}

Bank berasal dari kata bangue (Bahasa Perancis) dan dari kata banco (Bahasa Italia) yang berarti peti/ lemari atau bangku. Peti/ lemari dan bangku menjelaskan fungsi dasar dari bank komersial,yaitu : pertama, menyediakan tempat untuk menitipkan uang dengan aman (safe keeping function), kedua, menyediakan alat pembayaran untuk membeli barang dan jasa (transaction (unction $)^{10}$. Sedangkan pengertian dari Bank Syariah adalah bank yang beroperasi sesuai dengan prinsip-prinsip syariah Islam, Bank Syariah ini tata cara beroperasinya mengacu kepada ketentuan - ketentuan $\mathrm{Al}$ - Qur'an dan Hadist $^{11}$.Bank yang beroperasi sesuai dengan prinsip - prinsip syariah Islam maksudnya adalah bank yang beroperasinya itu mengikuti ketentuan ketentuan syariah Islam. Khususnya yang meliputi tata cara bermuamalah secara Islam. Maka untuk membedakan antara Bank Konvensional dengan Bank Syariah adalah dari prinsip, ketentuan dan tata cara yang terjadi didalamnya.

Bank yang prinsip syariah tidak dikenal istilah bunga dalam memberika jasanya kepada nasabah (konsumen). Prinsip syariah yang diberikan adalah pembiayaan sesuai dengan syariat hukum islam. Prinsip yang diterapkan oleh Bank Syariah adalah pembiayaan berdasarkan prinsip bagi hasil (mudharabah), pembiayaan berdasarkan prinsip penyertaan modal (musharakah), prinsip jual beli barang dengan memperolah keuntungan (murabahah) atau pembiayaan modal berdasarkan prinsip sewa murni (ijarah)

\section{Implementasi Bank Syariah}

\section{a. Karakteristik Bank Syariah}

10 M. Syafi' i Antonio, Dasar- Dasar Manajemen Bank Syariah, (Jakarta: Pustaka Alfabeta, cet ke-4, 2006), hlm 2.

${ }^{11}$ Edy Wibowo Dkk, Mengapa Memilih Bank Syariah", (Bogor, Ghalia Indonesia, 2005) hlm 33 
Dalam bertransaksi Bank Syariah tidak mengenal istilah bunga, melainkan bagi hasil yang sama memberikan keuntungan bagi nasabah (konsumen). Hanya saja yang membedakannya adalah pentuah harganya, dimana Bank Syariah mengharamkan penggunaan bunga tertentu pada produk produknya..Karakteristik khusus Bank Syariah adalah sebagai berikut ${ }^{12}$ :

a) Pelarangan riba dalam berbagai bentuknya

b) Tidak mengenal konsep nilai waktu dan uang ( time value of money)

c) Konsep uang sebagai alat tukar bukan sebagai komoditas

d) Tidak diperkenankan melakukan kegiatan yang bersifat spekulatif

e) Tidak diperkenankan menggunakan dua harga untuk satu barang

f) Tidak diperkenankan dua transaksi dalam satu akad.

\section{b. Fungsi Bank Syariah}

Bank Syariah memili peran dalam meningkatkan perekonomian Indonesia, sebagai salah satu penghimpun dana bagi masyarakat seperti halnya Bank Konvensional. Bank Syariah juga memiliki peran sebagai berikut ${ }^{13}$ :

a) Sebagai pelengkap dari Bank yang telah ada, dan menyediakan alternatif cara kerja perbankan yang memuaskan penggunanya

b) Sebagai satu sarana untuk meningkatkan partisipasi masyarakat banyak dalam pembangunan nasional dan mengurangi kesenjangan sosial ekonomi

c) Menciptakan lapangan pekerjaan baru

d) Sebagai sarana untuk menunjang peningkatan pendapatan masyarakat Selain peran, Bank Syariah juga memiliki fungsi sebagai berikut ${ }^{14}$ :

a) Manager investasi, yaitu Bank Syariah sebagai pemilik dana dari dana yang dihimpun (dalam perbankan lazim disebut sebagai deposan atau penabung)

${ }^{12}$ Ikatan Akuntansi Indonesia, Kerangka Dasar Penyusunan dan Penyajian Laporan Keuangan Bank Syariah, (Jakarta, Dewan Standart Akuntansi Keuangan Ikatan Akuntansi Indonesia, 2012), hlm 2

${ }^{13}$ Ibid, hlm 11

${ }^{14}$ Wiroso, Penghimpunan Dana dan Distribusi Hasil Usaha Bank Syariah, (PT. Grasindo, Jakarta, 2005), hlm 10 
karena besar kecilnya pendapatan yang diterima dari pemilik dana bergantung pada pendapatan yang diterima oleh Bank Syariah dalam mengelola dana secara keahlian, profesionalisme dan kehati - hatian.

b) Investor, yaitu mengivensikan dana yang dimilikinya maupun dana nasabah

\section{c.Prinsip Bank Syariah}

. Ada tiga pilar yang dijalankan oleh Bank Syariah yaitu :

a. Aqidah

Adalah komponen ajaran islam yang mengatur tentang keyakinan atas keberadaan Allah S.W.T sehingga harus menjadi keimanan seseorang muslim manakala melakukan berbagai aktivitas.

b. Syariah

Yaitu komponen ajaran islam yang mengatur tentang kehidupan seseorang muslim baik dalam ibadah maupun dalam bidang muamalah.

c. Akhlaq

Adalah landasan perilaku dan kepribadian yang mencirikan dirinya sebagai seorang muslim yang taat syariah dan aqidah.

\section{PEMBAHASAN}

\section{Implementasi Perlindungan Konsumen}

Konsumen dapat diartikan sebagai pemakai terakhir dari produk yang diserahkan kepada mereka dari pengusaha. Nasabah dalam konteks Undang - Undang Nomor 10 Tahun 1998 tentang perubahan atas Undang - Undang Nomor 7 Tahun 1992 tentang Perbankan dibedakan menjadi dua, yaitu nasabah penyimpan dan nasabah debitur yang dapat diartikan sebagai berikut

a.Nasabah penyimpan

Adalah nasabah yang menempatkan dananya di Bank dalam bentuk simpanan berdasarkan perjanjian bank dengan nasabah yang bersangkutan 
b.Nasabah debitur

Adalah nasabah yang memperoleh fasilitas kredit atau pembiayaan berdasarkan prinsip syariah atau yang dipersamakan dengan itu berdasarkan perjanjian bank dengan nasabah yang berkaitan.

Bila dikaji mengenai akibat hukum yang timbul secara lebih dalam, pada setiap transaksi akan menimbulkan hak dan kewajian bagi masing - masing pihak. Dari situ maka akan muncul kemungkinan pelanggaran hukum baik sengaja atau disengaja. Untuk itu, perlu diadakan upaya pencegahan maupun perlindungan tertutama perlindungan terhadap konsumen atau disini disebut nasabah. Hubungan hukum yang dimaksud adalah hubungan yang lahir dari suatu perjanjian antara para pihak mengenai harta benda kekayaan dimana pihak satu berhak menuntut sesuatu dari yang lainnya.

Dua fungsi utama Bank adalah mengumpulkan dana dan menyalurkan dana, penyaluran dana dilakukan Bank Syariah adalah pembiyaan bagi nasabah yang membutuhkan. Baik dalam pengajuan modal usaha, konsumsi atau pengajuan kredit lainnya. Mudharabah dan Musyarakah adalah contok produk dari Bank Syariah, yang telah diterapkan oleh para pelaku bisnis. Selain mengumpulkan dan menyalurkan dana, bank juga menawarkan sistem simpan dan pinjam.

Hubungan simpan pinjam ini diharapkan dapat menjadi suatu hubungan yang saling menguntungkan. Dalam Islam hubungan pinjam meminjam tidak dilarang, hubungan pinjam meminjam bahkan dianjurkan karena selain saling menguntungkan juga dapat berdampak timbulnya hubungan persaudaraan. Para pihak yang melakukan perjanjian yang perlu diperhatikan adalah subjek hukum dari nasabah baik perorangan/ badan hukum. Apabila perorangan maka harus didapat status/ data nasabah sudah menikah/ belum, sehingga diperlukan ijin suami/ istri. Apabila badan hukum perlu diperhatikan kewanangan pengurus dalam melakukan tindakan hukum diperlukan ijin 
dari komisaris. Perjanjian Bank Syariah juga memuat Pasal berdasarkan hukum positif dan tidak bertentangan dengan syariah islam,

Klausula yang dimaksud adalah :

a. Definisi yang digunakan termasuk istilah Syariah.

b. Keterangan mengenai fasilitas pembiayaan yang diberikan seperti besarnya jumlah pembiayaan, jangka waktu harus juga ditentukan, jenis pembiayaan (Murabahah, Musyarakah, Mudharabah).

c. Pengunaan fasilitas pembiayaan

Nasabah harus mengerti, mengetahu dan menyepakati bahwa pembiayaan tersebut hanya untuk barang/ proyek tertentu.

d. Keuntungan dan pembiayaan

Setiap pembayaan yang diberikan oleh Bank Syariah akan diperoleh keuntungan, misalnya dalam sistem jual beli atau fasilitas Murabahah akan didapat keuntungan yang disebut margin keuntungan. Margin keuntungan baik sendiri ataupun secara bersama dengan pokok pembiayaan akan diangsur setiap bulan sesuai kesepakatan.

e. Barang agunan secara Syariah

f. Biaya yang dibebankan

Adalah biaya administrasi sebesar $1 \%$ dari total pembiayaan.

g.Pengutamaan pembayaran

Pada Bank Syariah tidak dikenakan denda terhadap setiap kewajiban pembayaran yang terlambat sebagaimana yang tidak ditetapkan dalam pembayaran. Oleh karena itu nasabah harus mengutamakan melakukan angsuran pembayaran atau cicilan atas pembiayaan tertib dan teratur daripada kewajiban pembayaran kepada pihak lain.

h.Peristiwa cidera janji

Nasabah dapat dinyatakan wanprestasi atau cidera janji apabila tidak melaksanakan kewajiban yang terutang dan disepakati dalam perjanjian pembiayaan. 
i.Penutup

Dalam perjanjian pembiayaan Bank Syariah hamper sama dengan perjanjian pembiayaan pada Bank Konvensional. Umumnya akan dijelaskan mengenai segala biaya yang timbul atas perjanjian pembiayaan, domisili masing - masing pihak ditutup dengan penandatangan oleh para pihak dan saksi ${ }^{15}$.

Dalam mengkaji mengenai Undang - Undang No. 21 Tahun 2008 tentang Bank Syariah tentu kita harus mengetahu terlebih dahulu menengai yang menjadi dasar diterapkannya peraturan tersebut. Perlindungan hukum kepada nasabah pada perbankan menurut kajian Undang - Undang No. 21 Tahun 2008 salah satu upaya demi menjamin kepastian hukum bagi nasabah. Seperti bunyi Pasal 38 ayat (1) “.Sebelum mengkaji lebih dalam mengenai implementasi perlindungan hukum, alangkah baiknya kita terlebih dahulu mengenail landasan atau dasar hukum atas berlakunya UUPS, berikut penjelasannya :

\section{a). Kewajiban Nasabah}

1. Membaca dan mengikuti petunjuk informasi dan prosedur pemakaian barang atau jasa

2. Beritikad baik dalam melakukan transaksi pembelian barang atau jasa

3. Membayar sesuai nilai yang disepakati

4. Mengikuti upaya penyelesaian hukum sengketa perlindungan konsumen secara utuh.

\section{b). Hak Nasabah}

1. Berhak untuk mengetahui secara terperinci tentang produk - produk perbankan yang ditawarkan dan juga atas transparansi informasi produk bank. Hal ini merupakan hak utama dari nasabah, sehingga nasabah harus mendapatkan penjelasan yang jelas, terperinci dengan bahasa mudah dimengerti dan juga kesetaraan maupun keseimbangan dalam perjanjian perbankan.

\footnotetext{
${ }^{15}$ Modul tentang perjanjian Pembiayaan Bank Syariah, yang dibuat oleh BPRS Margarizki Bahagia, untuk kalangan sendiri, tidak dipublikasikan.
} 
2. Berhak untuk mendapatkan bunga (bagi hasil) atas produk tabungan dan deposito yang telah dijanjikan terlebih dahulu.

3. Berhak mendapatkan layanan jasa yang diberikan oleh Bank seperti fasilitas ATM, mendapatkan laporan atas transaksi, mendapatkan agunan kembali bila kredit yang dipinjam telah lunas, dan mendapatkan jasa uang pelelangan dalam hal agunan dijual untuk melunasi kredit yang tidak dibayar.

4. Berhak mendapatkan uang rupiah dalam kondisi asli, masih berlaku sebagai alat pembayaran yang sah, layak edar, dan jenis pecahan ataupun nominal yang sesuai dengan kebutuhan konsumen.

5. Berhak memberikan pengaduan dan wajib ditindaklanjuti.

6. Berhak mendapatkan kompensasi, ganti rugi atau penggantian atas kerugian akibat penggunaan, pemakaian, dan pemanfaatan barang/ jasa yang diberikan. Kompensasi atau ganti rugi wajib diberikan jika barang atau jasa yang diterima tidak sesuai ${ }^{16}$.

7. Berhak mendapatkan uang rupiah dalam kondisi asli, masih berlaku sebagai alat pembayaran yang sah, layak edar dan jenis pecahan atau nominal yang sesuai dengan kebutuhan konsumen.

8. Berhak memberikan pengaduan dan wajib ditindaklanjuti.

9. Berhak mendapatkan kompensasi, ganti rugi atau penggantian atas kerugian akibat penggunaan, pemakaian, dan pemanfaatan barang/ jasa yang diberikan. Kompensasi atau ganti rugi wajib diberikan jika barang atau jasa yang diterima tidak sesuai.

10. Berhak memberikan pengaduan dan wajib ditindaklanjuti.

11. Berhak mendapatkan kompensasi, ganti rugi atau penggantian atas kerugian akibat penggunaan, pemakaian, dan pemanfaatan barang/ jasa yang diberikan. 
Kompensasi atau ganti rugi wajib diberikan jika barang atau jasa yang diterima tidak sesuai

Penjelasan atas Undang - Undang No. 21 Tahun 2008 Pasal 3 yaitu mengenai tujuan Bank Syariah sebagai salah satu penunjang pembangunan nasional. Yaitu kegiatan usaha yang berasaskan prinsip syariah antara lain kegiatan ekonomi yang tidak mengandung unsur riba, maisir dan gharar. Perlindungan nasabah menurut Undang Undang No. 21 Tahun 2008 tentang Perbankan Syariah (selanjutnya disebut UU Perbankan Syariah atau UUPS) adalah segala upaya yang menjamin adanya kepastian hukum untuk memberikan perlindungan kepada konsumen pengguna jasa Perbankan Syariah sesuai dengan ketentuan UUPS yang meliputi adalah mekanisme pengaduan nasabah, meningkatkan transparansi produk, dan edukasi terhadap nasabah.

Secara eksplisit ketentuan mengenai nasabah debitur dalam Undang - Undang No. 10 Tahun 1998, sebagian besar Pasal nya hanya focus terhadap aspek kepentingan bank. Tentu ini menjadikan perlindungan terhadap nasabah menjadi lemah, baik ditinjau dari perjanjian tertulisnya misalnya saja jika pada biasanya perjanjian kredit menggunakan kontrak yang membebani nasabah kewajiban dan tanggung jawab dan pada akhirnya pihak bank memiliki tanggung jawab yang tidak sebesar nasabah.

Tidak terkecuali terjadi pada Bank Syariah, akan tetapi secara khusus Bank Syariah kegiatan usahanya dilaksakan menggunakan syariat islam. Dengan berlakunya Undang - Undang No. 21 Tahun 2008 tentu menjadi angin segar bagi para nasabah. Tercemin Bab II Pasal 2 yang menjelaskan mengenai kegiatan usaha yang berdasarkan prinsip syariah yang tidak mengandung unsur :

- Riba'

Yaitu penambahan pendapatan secara tidak sah (batil) antara lain dalam transaksi pertukaran sejenis yang tidak sama kualitasnya, kuantitasnya atau 
dalam transaksi pinjam - meminjam yang wajib syaratnya adalah membebani nasabah membayar tertanggung berlipat ganda kepada pihak bank.

- Maisir

Yaitu transaksi yang digantungkan kepada suatu keadaan yang tidak pasti dan bersifat untung - untungan.

- Gharar

Yaitu transaksi yang objeknya tidak jelas, tidak dimiliki, tidak diketahui keberadaanya, atau tidak dapat diserahkan pada saat transaksi dilakukan kecuali diatur dalam syaria a. haram (adalah objeknya yang dilarang oleh hukum syariah, b. zalim, yaitu transaksi yang dapat menimbulkan ketidak adilan bagi pihak lainnya.

Dalam mengkaji mengenai Undang - Undang No. 21 Tahun 2008 tentang Bank Syariah tentu kita harus mengetahu terlebih dahulu mengenai yang menjadi dasar diterapkannya peraturan tersebut. Selain itu upaya perlindungan nasabah secara umum diperlukan sebuah mekanisme yang pasti. Selanjutnya mekanisme tersebut dilatarbelakangi oleh beberapa alasan, seperti : pertama, untuk peningkatan perlindungan dan pemberdayaan nasabah dalam rangka menjamin hak - hak nasabah dalam berhubungan dengan bank. Kedua, mempercepat tindak lanjut penanganan dan penyelesaian pengaduan nasabah, sehingga dapat menanggulangi resiko dan dapat meningkatkan kembali kepercayaan masyarakat terhadap lembaga perbankan.Kunci pokok dalam perlindungan nasabah Bank Syariah terletak pada hubungan antara nasabah dan pihak Bank Syariah.

\section{Kendala dan Solusi dalam Implementasi Perlindungan Konsumen}

1. Kendala yang dihadapi

Masalah - masalah yang kemungkinan timbul pada Bank Syariah adalah sebagai berikut : 
a. Pembiayaan Modal Kerja Syariah

Modal merupakan permasalahan penting yang senantiasa dihadapi oleh setiap orang yang merintis usaha. Permasalahan akan modal dan prospek mengenai keberhasilan Bank Syariah membuat perhitungan modal tidak dilandasi dengan ubudiyah sehingga terkesan semata - mata hanya mencari keuntungan.

b. Regulasi Bank Syariah

Seperti diketahui bahwa fungsi umum dari Undang - Undang adalah memberikan pengayoman terhadap kepastian hukum masyarakat, diharapkan Undang - Undang dapat berperan lebih dalam memberikan kepastian hukum bagi masyarakat.

Regulasi hukum yang berlaku sepenuhnya mengkoordinir dalam pelaksanaan operasional Bank Syariah, mengingat adanya sejumlah perbedaan dalam pelaksaan antara Bank Konvesional dengan Bank Syariah. Regulasi yang ada diharapkan dapat disesuaikan dengan ketentuan Bank Syariah sehingga regulasi tersebut dapat terlaksana secara efisian, relative dan dapat bersaing.

c. Minimnya Sumber Daya Manusia

Perkembangan Bank Syariah dalam menunjang ekonomi syariah berdampak makin menjamurnya Bank Syariah. Perkembangan ini tidak diikuti oleh Sumber Daya Manusia yang memadai, pengembangan SDM sangat dibutuhkan karena perkembangan Bank Syariah membutuhkan ketrampilan SDM guna meningkatkan kinerja Bank Syariah.

d. Tingkat Pemahaman dan Kepedulian Umat

Pemahaman dan kepedulian sebagian besar umat mengenai sistem dan prinsip syariah belum tepat, bahkan ada diantara ulama dan cendekiawan muslim sendiri masih belum ada kata sepakat untuk mendukung eksitensi Bank Syariah. 
Padahal ulama tidak hanya sekedar sosok yang menyebarkan ilmu, melainkan bisa menjadi sosok penggerak dan motivator masyarakat.

e. Sosialisasi Setengah Hati

Yang dimaksud sosialisasi adalah serangkaian kegiatan guna menginformasikan secara sempurna dan jelas kegiatan Bank Syariah kepada masyarakat. Yang menjadi dasar atau isi dari sosialisasi tersebut adalah memperkenalkan mekanisme, macam - maca transaksi, serta instrument - instrument Bank Syariah.

f. Piranti Moneter Ribawi

Bank Indonesia selaku penentu kebijakan perbankan harusnya menyiapkan piranti moneter yang sesuai dengan prinsip syariah. Piranti moneter yang ada pada saat ini masih mengacu pada sistem bunga (riba) sehingga belum bisa memenuhi dan mendukung kebijakan moneter dan kegiatan Bank Syariah ataupun pasar uang Bank Syariah.

g. Pelayanan publik

Salah satu pendukung semakin majunya Bank Syariah adalah dengan semakin baiknya pelayanan public yang diberikan. Pengertian lebih luas adalah Bank Syariah dalam beroperasi wajib memberikan jasa tentunya unsur pelayanan yang islami, baik secara maksimal. Tentu pula hal ini didukung SDM yang handal dibidangnya.

h. Pandangan Bank Syariah Belum tentu Islami Menggunakan nama syariah tidak dipungkiri menjadi daya Tarik sendiri terutama bagi nasabah yang beragama islam. Produk - produk Bank Syariah diperkenalkan sedemikian rupa guna menarik peminat, namun yang terjadi dilapangan banyaknya Bank Syariah yang masih menggunakan sistem riba. 
Hubungan yang terjalin antara nasabah dan pihak bank tentu tidak selamanya berjalan mulus, bukan suatu hal yang tidak mungkin bila terjadi perbedaan opini yang apabila tidak segera diselesaikan dapat berubah menjadi sengketa antara nasabah dan perbankan. Penyebab paling umum munculnya friksi (perbedaan opini) adalah :

- Informasi yang kurang jelas

Penyampaian informasi mengenai produk - produk dan jasa yang ditawarkan Bank Syariah yang kurang jelas, dapat menimbulkan friksi pada nasabah

- Pemahaman nasabah yang kurang

Dari penyampaian informasi yang kurang jelas, dapat mengakibatkan pemahaman nasabah yang kurang pula. Hal ini adalah hal yang sensisitif, karena jika sudah terjadi perbedaan pemahaman maka akan muncul masalah dikemudian hari yang bisa berujung pada sengketa.

- Ketimpangan hubungan antara nasabah dan bank Ketimpangan berarti ketidak adilan, yang dimaksud disini adalah cacat nya hubungan antara nasabah dengan pihak bank. Hal ini biasanya bermula dari ketidak jelasan informasi yang disampaikan oleh bank, ketidak pahaman nasabah dan berujung pada ketimpangan hubungan antara nasabah dan bank.

- Tidak adanya saluran yang menengahi

Adanya sengketa antara nasabah dan pihak bank sepatutnya diselesaikan dengan bantuan pihak ke 3, agar kejelasan sengketa menjadi adil mengingat jika pengadil di ambil dari salah satu pihak maka bisa terjadi ketimpangan.

2. Solusi Untuk Menyikapi Permasalahan Bank Syariah

Menyikapi kendala - kendala yang muncul seperti yang sudah penulis uraikan diatas, maka akan timbul solusi sebagai berikut

- Berfokus pada Syariah Islam 
Dalam membangun Bank Syariah yang berasaskan pada Syariah Islam, haruslah memiliki tujuan untuk menolong sesame tanpa adanya tujuan untuk menguntungkan diri sendiri.

- Regulasi Bank Syariah

Meskipun implementasi Bank Konvensional dengan Bank Syariah memiliki perbedaan karena Bank Konvensional menganut Undang - Undang sedangkan Bank Syariah dengan Syariah Islam. Regulasi yang berlaku harus tetap dijalankan sesuai kiblat masing - masing dan tetap bertujuan untuk memberikan kepastian dan keadilan pada masyarakat.

- Peningkatan Sumber Daya Manusia

Jika pada permasalahan muncul kurangnya SDM maka sebaiknya pihak Bank atau bahkan pihak Pemerintah lebihaktif lagi untuk menggali kompetensi kompetensi yang dimiliki masyarakat tertutama pada masyarakat kurang mampu. Dengan cara memberikan sosialiasi, sistem kuliah dengan biaya murah atau pelatihan - pelatihan bersertifikat yang nantinya dapat digunakan untuk melamar pekerjaan di bank.

Sebaliknya, masyarakat diminta untuk ikut andil dalam peningkatan SDM dengan cara aktif untuk mengikuti sosialisasi, perkuliahan atau pelatihan pelatihan yang diadakan oleh pihak perbankan atau pemerintah setempat. Karena selain dapat menambah pengetahuan juga hasil pelatihan dapat dipergunakan untuk mencari pekerjaan. Dengan peningkatan SDM ini maka akan menjadi bibit yang bagus dalam penyampaian informasi mengenai Bank Syariah kepada masyarakat jelas. Tentu SDM yang terpilih tidak hanya memiliki keahlian atau kepandaian yang bagus, tapi juga harus dibekali dengan ilmu attitude yang baik.

- Meningkatkan kepedulian ummat 
Jika SDM sudah ditingkatkan, diharapkan ini dapat mempermudah menyampaikan informasi dan memancing masyarakat luas untuk lebih aktif lagi. Sistem dan prinsip Bank Syariah yang tadinya belum diketahui dapat diketahui langsung.

Selain itu, sebaiknya pihak Bank Syariah mengajak serta cendekiawan muslim dan ulama. Sebagai masyarakat yang mayoritas muslim, sungguh dianjurkan jika Bank Syariah mengajak ulama sebagai tokoh yang dianut sebagai salah satu ikon untuk mengajak masyarakat bertrantaski di Bank Syariah.

- Sosialisasi sepenuh Hati

Bank Syariah dapat maju apabila mendapat dukungan penuh dari nasabah, ketidak tahuan nasabah mengenai produk dan jasa Bank Syariah tentunya akan menjadi pekerjaan rumah bagi pihak bank. Sosialiasi dengan bahasa yang mudah dimengerti tentu akan lebih mudah dipahami.

- Bank Syariah tidak menganut riba'

Sebagai Bank yang menganut pada syariah islam, tentu riba' haram dijalankan pada sistem Bank Syariah. Ini akan menjadi modal utama Bank Syariah untuk menarik nasabah sebanyak - banyaknya. Tentu ini harus betul diterapkan pada sistem Bank Syariah, karena jika bank sendiri tidak konsisten ini akan menimbulkan ketidak percayaan masyarakat terhadap Bank Syariah.

- Pelayanan Publik

Pengertian lebih luas adalah Bank Syariah dalam beroperasi wajib memberikan jasa tentunya unsur pelayanan yang islami, baik secara maksimal. Tentu pula hal ini didukung SDM yang handal dibidangnya.

- Bank Syariah yang Islami

Pandangan mengenai Bank Syariah belum islami tentu menjadi pekerjaan rumah bagi bank, cara yang ditempuh bank sebaiknya adalah dengan benar - 
benar tidak menganut sistem riba' dan secara penuh melaksanakan segala kegiatan transaksi sesuai dengan syariah islam.

Berdasarkan solusi yang diuraikan diatas, kendala yang terjadi pada Bank Syariah diharapkan berkurang. Hubungan yang terjalin anatara nasabah dengan Bank Syariah dapat diselesaikan hingga tidak berujung sengketa pada pengadilan. Mediasi menjadi jalur tempuh utama bagi penyelesaian sengketa. Lebih lanjut saran yang dapat penulis uraikan adalah :

a. Bagi Bank

- Mensosialisasikan produk dengan menonjolkan manfaat dari suatu produk agar informasi yang diberikan bank lebih mudah dipahami oleh nasabah. Dan informasi yang disampaikan secara menarik dapat menambah simpati sehingga dapat menjadi daya tarik bagi masyarakat.

- Memperhatikan faktor pelayanan karena faktor pelayanan lebih dominan daripada faktor lainnya.

- Perlu diadakannya penilaian mengenai sejauh mana kepuasan nasabah terhadap fasilitas dan pelayanan Bank Syariah, agar pihak bank bisa meningkatkan kualitasnya.

b. Bagi Pemerintah

- Mengadakan audit guna menilah bank - bank mana saja yang perlu ditindak dan mana saja yang perlu diapresiasi.

- Mengadakan sosialisasi mengenai perlindungan konsumen kepada masyarakat luas tidak terkecuali pihak bank nasabah. Sosialisasi ini bertujuan agar pihak - pihak yang berhubungan dapat mengetahui hak dan kewajiban masing masing. Dan yang paling utama, dapat mengetahui tata cara mengadu jika ada kendala. 
- Lebih aktif dalam menindak jika ada bank yang terbukti melakukan pelanggaran

- Mendampingi pihak nasabah jika mengalami kerugian yang diakibatkan pihak bank.

c. Bagi nasabah

- Aktif untuk mengetahui ilmu - ilmu baru mengenai Bank Syariah baik melalui informasi dari bank atau dari luar bank

- Aktif berkomunikasi dengan pihak bank jika merasa ada yang janggal

\section{E. PENUTUP}

Implementasi Perlindungan Konsumen Menurut Undang - Undang No. 21 Tahun 2008 Tentang Perbankan Syariah masih perlu diedukasi ke pihak nasabah dan pihak bank mengingat masih banyaknya ketimpangan hubungan yang terjadi antara kedua pihak. Dalam pengkajiannya, perlindungan konsumen Bank Syariah harus berpegang teguh pada enam pilar yang telah ditetapkan Bank Indonesia. Karena kesuksesan sebuah bank sangat bergantung terhadap kepercayaan masyarakat. Perlu diperhatikan tentang kajian formulasi perlindungan konsumen menurut Undang - Undang positif di Indonesia dan menurut syariat islam. Yakni meliputi persamaan dalam penyelesaian sengketa lewat jalur perdamaian, mediasi dan sistem peradilan. 


\section{DAFTAR PUSTAKA}

\section{BUKU}

Kasmir, Bank dan Lembaga Keuangan Lainnya ( Jakarta: PT. Grafindo Persada, 2011) cet-7 Nyoman Moena, Rangkuman Sajian Analisi Efisiensi dan Aktifitas Hukum Perbankan, Makalah Pada Pertemuan BPHN, Desember 1996

Dewi Nurul Musjtari, Penyelesaian Sengketa dalam Praktik Perbankan Syariah, (Yogyakarta: Nuha Medika, 2012)

Amin Aziz, Tantangan, Prospek dan Strategi Sistem Perekonomian syariah di Indonesia dilihat dari pengalaman pengembangan BMTJakarta, PINBUK, 1996,)

Edy Wibowo, Mengapa Memilih Bank Syariah? (Bogor, Ghalia Indonesia, 2015) Ahmad Ashar Basyir, artikel pada Berbagai Aspek Ekonomi Islam (editor M. Rusli Karim), (Yogyakarta, P3EI - FE UII bekerjasama dengan Penerbit Tiara Wacana, 1992)

Ahmad Nahrawi, Ensiklopedia Imam Syafi'I terj. Usman Sya'roni ( Jakarta, PT. Mizan Publika, 2008)

Muhammad Syafi'i. Antonio, Bank Syariah Dari Teori ke Praktik, ( Jakarta: Gemma Insani Perss, 2001)

Muhammad, Tehnik Perhitungan Bagi Hasil dan Profit Margin Pada Bank Syariah ( Yogyakarta: UII Press, 2001 )

M. Syafi'i Antonio, Dasar- Dasar Manajemen Bank Syariah, (Jakarta: Pustaka Alfabeta, cet ke-4, 2006)

Edy Wibowo Dkk, Mengapa Memilih Bank Syariah”, (Bogor, Ghalia Indonesia, 2005)

Ikatan Akuntansi Indonesia, Kerangka Dasar Penyusunan dan Penyajian Laporan Keuangan Bank Syariah, (Jakarta, Dewan Standart Akuntansi Keuangan Ikatan Akuntansi Indonesia, 2012)

Wiroso, Penghimpunan Dana dan Distribusi Hasil Usaha Bank Syariah, (PT. Grasindo, Jakarta, 2005)

\section{JURNAL}

Abdullah Kelib, Sodkul Amin, Analisis Terhadap Pelaksanaan Aqad Pembiayaan Dengan Prinsip Mudharabah Pada Bank Syariah Dalam Kajian UU No. 21 Tahun 2008 Tentang Perbankan Syariah, Jurnal Ius 
e-ISSN : 2621-4105

Constituendum Vol 2 No 1, Magister Hukum Universitas Semarang, 2017 Semarang.

\section{INTERNET}

(https://sikapiuangmu.ojk.go.id/FrontEnd/CMS/Article/10438, Diakses 2 Juli 2019, 2019) 